\title{
フォトニック結晶面発光レーザーの多樣なビームパターン
}

\author{
酒井 恭輔 ${ }^{1,2}$, 野田 准 $^{2}$ \\ 京都大学 次世代開拓研究ユニット \\ 2京都大学 工学研究科電子工学専攻 ( $=615-8175$ 京都府京都市西京区京都大学桂A1-328)
}

\section{Novel Beam Patterns from Photonic-Crystal Surface-Emitting Laser}

\author{
Kyosuke SAKAI ${ }^{1,2}$ and Susumu NODA ${ }^{2}$ \\ ${ }^{1}$ Kyoto University Pioneering Research Unit for Next Generation \\ ${ }^{2}$ Department of Electronic Science and Engineering, Kyoto University, Kyotodaigaku-Katsura, Nishikyo-ku, Kyoto $615-8510$
}

(Received April 22, 2009)

\begin{abstract}
Compact lasers that can produce a range of beam patterns are important for progress in several areas, including the improvement of optical tweezers, microfluidics and ultra-high-resolution optical microscopes. Here we overview the recent progress of photonic-crystal surface-emitting lasers that produce a range of beam patterns. We have designed several types of photonic crystal cavities and successfully obtained a range of beam patterns including doughnut-shape, double or quadruplet doughnut shape as well as a single-peaked shape, with very small divergence angles of about $1^{\circ}$. Among the range of beam patterns, doughnut-shape beams have very important abilities such as optical manipulation of opaque particles or strong focusing to a size much less than the wavelength. We have also developed GaN-based devices and successfully obtained laser emission in blue-violet regime. Because of these novel features, the presented photonic-crystal surface-emitting lasers are promising light sources that open the avenue for next generation optical systems.
\end{abstract}

Key Words: Photonic-crystal surface-emitting lasers, Beam pattern control, Optical tweezers, Super resolution, Blue-violet laser

1. はじめに

フォトニック結晶面発光レーザー ${ }^{1-4)}$ は, 周期的な屈 折率分布を有するフォトニック結晶 ${ }^{5}$ を光共振器とした 半導体レーザーである. フォトニック結晶により共振 モードが規定されることから，2次元大面積での単一 モード発振が可能であり, 原理的に高出力かつ単一モー ド動作に適したレーザーである。さらに，フォトニック 結晶構造を制御することにより，多様なビームパターン を形成することが可能となる ${ }^{6}$ 。このような特長から， フォトニック結晶面発光レーザーは，単一モードでの高 出力動作およびビームパターン制御が可能なレーザーと して，近年，大きな注目を集めている。

フォトニック結晶面発光レーザーの研究は，主に我々 のグループを中心に進められてきた。電流注入による室 温連続動作の実現 皇初めとして, フォトニック結晶に 形成される共振モードの電磁界分布 ${ }^{4}$ や $Q$ 值の解析 ${ }^{8}$, フォトニックバンド構造中での発振バンド端の同定9), 結合波理論に基づいた簡便な共振モード解析 ${ }^{10)}$ など, 基 本的な動作特性の理解から, 高出力化へ向けた具体的な
構造設計 ${ }^{11,12}$ まで着実な成果を挙げている。また，動作 波長については, 当初, 可視 ${ }^{2)} や$ 近赤外領域 ${ }^{1,7)}$ でのデバ イスが研究されていたが，現在では，中赤外領域 ${ }^{13)}$ や青 紫色領域 ${ }^{14)}$ でのデバイスも実現されており，本レーザー の可能性は，ますます広がりを見せているところであ る.

本稿では, フォトニック結晶面発光レーザーの多様な ビームパターンについて, その発生原理と興味深い応用 可能性を解説する。 また，最近実現に成功した青紫色領 域でのデバイスについても紹介する，2節において，ま ずフォトニック結晶面発光レーザーの動作原理を説明 し, 垂直共振器面発光型レーザー(VCSEL) との違いの 理解を図る。3節では，フォトニック結晶構造による電 磁界分布の制御について解説したのち，実際に得られた ビームパターンを示す。中でも，ドーナッツ状のビーム は，偏光が特徵的な分布をしており，波長の数分の1以 下への微小な集光 ${ }^{15)}$ や，不透明微粒子の光ピンセット ${ }^{16)}$ 等, 興味深い応用が考えられる，4節では，一例として， 不透明微粒子の光ピンセットについて説明する。5節で は，最近実現した青紫色領域でのデバイスについて紹介 
する。

\section{2. フォトニック結晶面発光レーザーの動作原理}

Fig. 1に, フォトニック結晶面発光レーザーの模式図 を示す，本レーザーでは，活性層の近傍に形成された フォトニック結晶が, 光共振器として動作する。フフト ニック結晶中を伝搬する光(白矢印)は，右図に示すよう に, 結晶を構成する格子点により, 逆方向 $\left(-180^{\circ}\right.$ 方 向)へ回折されるとともに $+90^{\circ}$ 㧍よび $-90^{\circ}$ 方向へも回 折され(灰色矢印), 結果として等価な 4 つの方向一伝搬 する光が互いに結合しあう。こうした結合が共振器全域 で起こることにより，2次元的な共振モードが形成され ることになる，共振モードを形成する光の波長が結晶の 周期と一致する場合には，光は結晶面に対して垂直方向 へも回折されるため, 面発光レーザーとして動作する。

これが, フォトニック結晶面発光レーザーの動作原理で ある. 本特集号で多く取り上げられている垂直共振器型 面発光レーザーでは，基板の上下面に形成された反射鏡 により共振モードが形成され，その一部が反射鏡を通過 して出力光として外部へ放射される. 発振を単一モード とするためには, 反射鏡に平行方向の共振領域の大きさ を制限する必要があり, 単一モードでの大面積動作は原 理的に困難である.

一方，フォトニック結晶面発光レーザーに执いては, 共振モードはフォトニック結晶の2次元的な周期性(分布 帰還効果)により決定されるため, 結晶面積を変化させ ても同一のモードが形成される。面積を拡大させても共 振モードは変化しないため, 大面積かつ単一縦横モード での高出力動作が可能となる。 こうした特長に加えて, フォトニック結晶面発光レーザーでは, 面積の大きな結 晶面に垂直方向に光が出射されるため, 得られるレー ザービームの広がり角は小さく, ビームパターンは, 結 晶内での共振モードの電磁界分布を反映した特徴を有す ることになる，共振モードの電磁界分布は，フォトニッ

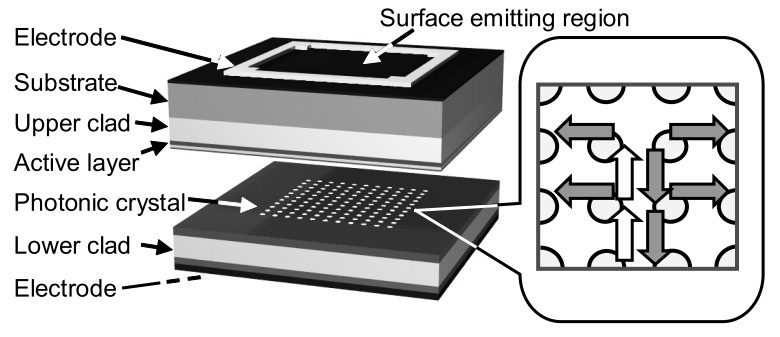

Fig. 1 Schematic structure of photonic-crystal surface emitting laser. The material system is InGaAs/ $\mathrm{GaAs}$, and the gain peak of the active layer is set at $\sim 980 \mathrm{~nm}$. The inset shows the diffraction of light waves propagating in the photonic crystal.

ク結晶の構造により制御可能であり, 結晶構造の設計に より多様なビームパターンが実現される，以下に，その 具体例を示していく.

\section{3. 結晶構造制御による多様なビームパターンの生成}

Fig. 2に, フォトニック結晶面内での共振モードの電 磁界分布を示す，色の濃淡が磁界分布を示し，矢印が電 界分布を示している。ここで検討するフォトニック結晶 は, 空気孔が正方格子状に配列したものであり, ビーム パターンの制御には，空気孔の形状㧍よび結晶周期の位 相ずれを用いる。

まず，空気孔の形状を，(a)真円抢よび (b) 三角形とし た場合について，Fig. 3を用いて説明する。空気孔の周 りの電界を矢印で示す，真円の場合には，その対称性の 高さを反映して，電界が空気孔中心に対して反対称な分 布をしていることが分かる。一方，対称性を崩すため空 気孔を三角形とすると， $x$ 軸に沿った方向に電界が非対 称となる。こうした対称性の違いは, 結晶面に対して垂 直方向へ光が回折される際の干渉効果に現れる. 空気孔 が真円の場合には，空気孔中心に対して電界が反対称で あるため, 結晶面に垂直なz軸上に扔いては，打ち消し

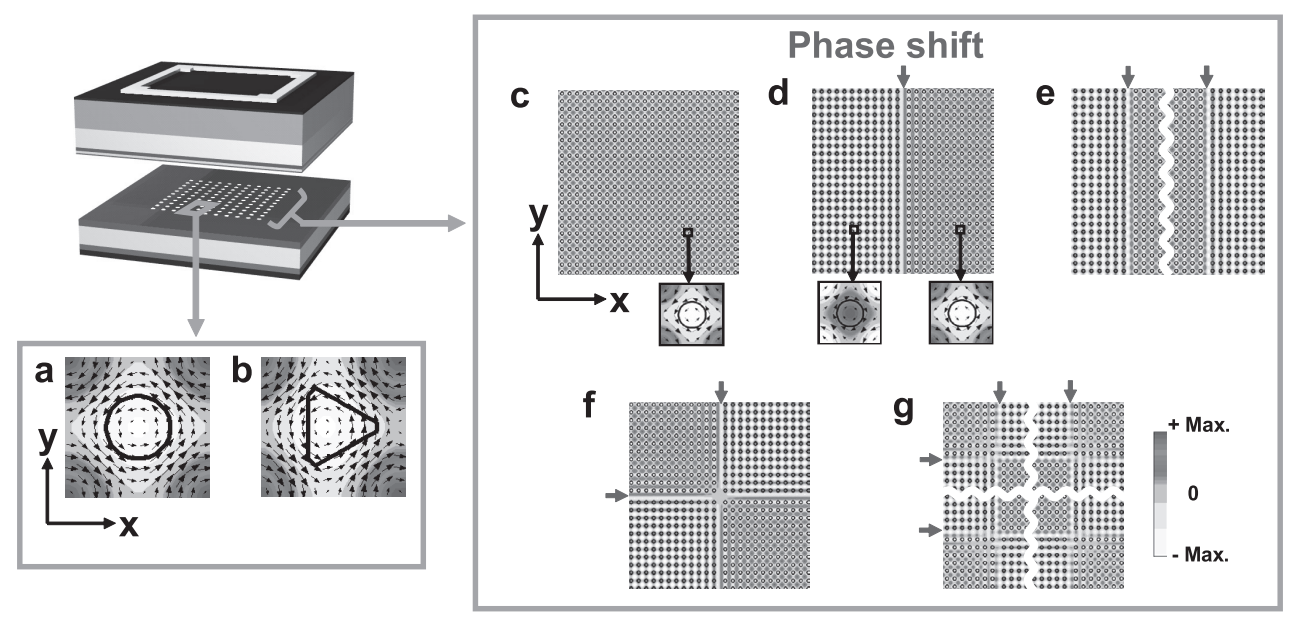

Fig. 2 Electromagnetic-field distributions inside one unit cell for (a) circular and (b) triangular air hole. (d)-(h). Various 0.5a lattice shifts, where $a$ is the lattice constant, and corresponding electromagnetic-field distributions inside the device: (d), no shift; (e), one shift; (f), parallel double shifts; (g), crossed shifts; (h), double crossed shifts. Red arrow indicates the position where the phase shift is introduced. ${ }^{6)}$ 


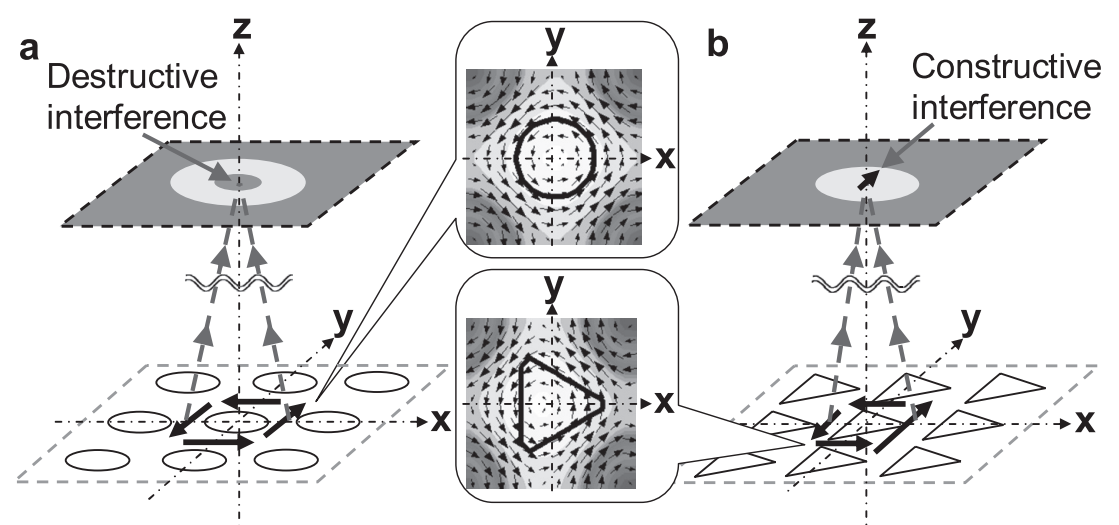

Fig. 3 Schematic diagram of interference in the surface emission from the device with (a) circular and (b) triangular air holes.

合いの干渉が生じ光強度は零となる。z軸上以外では光 強度が現れるため, ビームパターンはドーナッツ状とな る。一方, 空気孔が三角形の場合には, $x$ 方向には電界 は非対称となることから， $z$ 軸上での打ち消し合いが弱 まり, 単峰のビームパターンとなる。 Fig. 4に, 実際に 形成したフォトニック結晶の電子顕微鏡写真 (左)と得ら れたビームパターン(右)を示す。対称性を反映して, 確 かに，(a)真円の場合にはドーナッツ状のビームが得ら れるのに対し, (f) 三角形の場合には単峰のビームが得 られていることが分かる。また，広がり角は双方とも 1 程度と半導体レーザーから出射されるビームとして は，非常に小さいことも特筆すべき特長である。

ビームパターンは, 空気孔の形状のみならず, Fig. 2 (c) - (g) に示すような結晶周期の位相ずれによっても制 御することができる. Fig. 2 (c) は, 位相ずれのない場 合の電磁界分布であるが, この構造の中心に半周期の位 相ずれを導入すると, Fig. 2 (d) に示す様に位相ずれの 左右で反転した電磁界分布が得られる。ささらに，位相ず れの導入の方法により, (e) $-(\mathrm{g})$ に示すような多様な電 磁界分布が形成可能である．真円の空気孔からなるフォ トニック結晶に位相ずれを導入したサンプルから実際に
得られたビームパターンを, Fig. 4 (b)-(e)に示す. 1本 の位相ずれによりドーナッツパターンが2つになり，十 字の位相ずれによりドーナッツが4つになるなど，位相 ずれの導入により多様なビームパターンが実現できてい る.

以上，フォトニック結晶の構造制御により，半導体 レーザー単体から多様なビームパターンが実現可能であ ることを説明した。こうした多様なビームパターンの生 成は，応用上にも大きな意味をもつ。例えば，広がり角 が小さく等方的な単峰のビームにより，ビーム整形用の レンズが省略できるなど，既存の光学システムの簡素化 が期待される.さらに, 真円の空気孔から出射される ドーナッツ状のビームは, その電界方向の特徵から集光 点で興味深い性質を示すことが期待されている. Fig. 4 の挿入図に, フォトニック結晶面発光レーザーより得ら れているドーナッツ状ビームの2種の偏光状態を示す. 電界の振動方向がドーナッツの周回方向へ揃った $(\mathrm{g})$ 方 位偏光と, 動径方向へ揃った $(\mathrm{h})$ 径偏光である。これら は, 共振モードの電界の偏光方向により選択可能であ り, 電界がフォトニック結晶に平行に偏光している Transverse Electric(TE) モードの場合は方位偏光が得ら
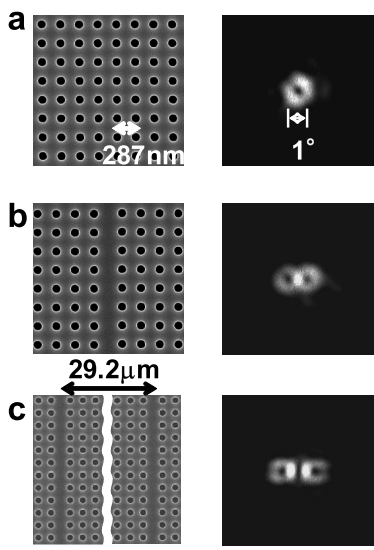

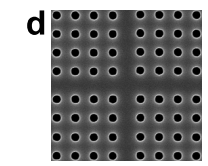

$29.2 \mu \mathrm{m}$
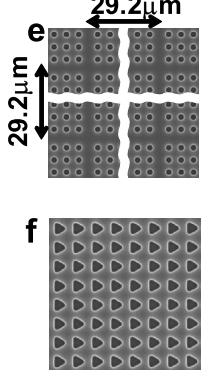
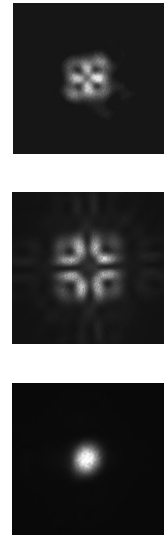

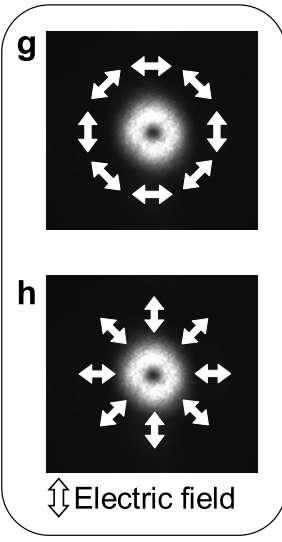

Fig. 4 A range of beam patterns produced by photonic-crystal lasers with engineered lattice points and/or lattice phases. (a)-(f), Scanning electron micrographs (SEM) of crystal structures (left panels) and observed beam patterns (right panels) for circular lattice points with no phase shifts, with one shift, with parallel double shifts, with crossed shifts and with double-crossed shifts, and for triangular lattice points with no shifts, respectively. Two types of polarization; (g) azimuthal and (h) radial polarization. ${ }^{6}$ 
れ，垂直方向に偏光しているTransverse Magnetic (TM) モードの場合には径偏光が得られる。これら電界方向の 違いは，集光した際に明確に現れ，それぞれについて興 味深い応用が期待される。方位偏光の場合には, ドー ナッツ状の集光点を形成することから，中心に不透明の 微粒子を捕捉する光ピンセットとして応用することが可 能である。一方, 径偏光の場合には, 波長の数分の 1 以 下の微小な集光点の形成が可能になると予想され, 光学 システムの分解能向上につながるビームとして期待を集 めている ${ }^{15,17)}$ 。次節では興味深い応用の一例として，方 位偏光ドーナッツ状ビームによる不透明微粒子の光ピン セット効果について解説する。

\section{4. ドーナツ状ビームによる光ピンセット}

Fig. 5 (a) に方位偏光ビームの集光の様子を示す. 光 軸を含む断面での電界方向は, 光軸に対して反対称と なっているため, 打ち消し合いの干渉により, 集光点に 招いて光軸上に光強度が存在しない. そのため, ドー ナッツ状の集光点が形成されることになる。こうした ドーナッツ状の集光点は, 不透明な微粒子の光ピンセッ トに大きな効果を発揮する. 光ピンセット ${ }^{18,19)}$ とは, 光 の放射圧により液中の微粒子を捕捉・操作する手法であ り, 生体細胞の切断や操作, マイクロ流体デバイス中で の粒子の移動や選別等に応用され始めている，微粒子が 透明な場合には，ガウスビームにより形成される単峰の 集光点で捕捉が可能である。しかし，不透明な場合に は，光の放射圧により微粒子がはじかれてしまい捕捉す ることができない，これに対し，ドーナッツ状の集光点 では，その中心に不透明な微粒子を閉じ达め捕捉するこ とが可能になる. Fig. 5 (b)-(d)に, 水中に分散した不 透明微粒子を捕捉した様子を示す ${ }^{16)}$. 白く見える集光点 の中心に, 大きさ約 $5 \mu \mathrm{m}$ 程度のタングステン微粒子が 捕捉され, 容器を移動した場合でも, 微粒子の位置は変
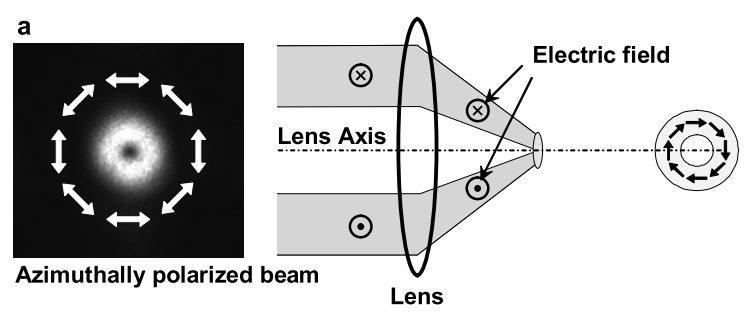

b
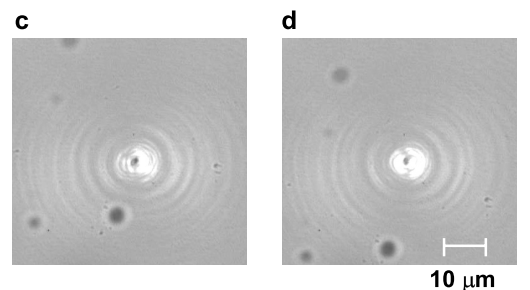

Tungsten particle

Fig. 5 (a) Schematic diagram of focusing for the azimuthally polarized beam. (b)-(d) Optical trapping of tungsten particle inside a doughnut-shape focus of the azimuthally polarized beam, while a sample stage was moved downward. ${ }^{13)}$
わらないことが分かる。なお実験には，波長 $980 \mathrm{~nm}$ ，光 出力 $10 \mathrm{~mW}$ の方位偏光ビームを用いた，気泡など屈折率 が溶媒より小さな微粒子も，単峰の集光点では捕捉でき ないが，ドーナッツ状の集光点では捕捉が可能である. また，透明な微粒子の場合でも，光強度の強い部分に捕 捉が可能であるため, ドーナッツ状の集光点を形成する 方位偏光ビームは, 微粒子の材質によらない光ピンセッ トを可能にするものと期待される.

\section{5. 青紫色領域での発振}

本節では，最近，発振に成功した青紫色領域で動作す

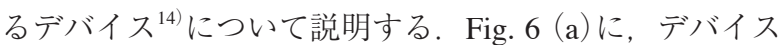
の断面構造についての模式図を示す。 InGaNの多重量子 井戸活性層の極近傍に, 空気孔と GaNからなるフォト ニック結晶を形成し，デバイス内部に埋め込んでいる. 我々は,こうした構造をAROG(air hole retained over growth）という新たな結晶成長方法により作製した。本 方法では，(0001)面上のGaNの結晶成長の際に，上方へ の成長速度に比べて，横方向への成長速度が大きいこと を利用している，空気孔を形成した後，孔内での結晶成 長を抑制する $\mathrm{SiO}_{2}$ 層を空気孔底部に堆積し，そのうえで GaNを成長させる。，その際，横方向の成長速度が大きい ことから，空気孔を覆う様に GaN層が成長することにな る。その結果, 綺麗な形状を維持した空気孔がデバイス 内部に埋め込まれることになる。Fig. 6 (b)にAROG成長 を行う前のフォトニック結晶の電子顕微鏡像を示す。直 径100 nm以下の空気孔が綺麗に形成されていることが 分かる。 ここで結晶構造は, 前節までの正方格子構造と
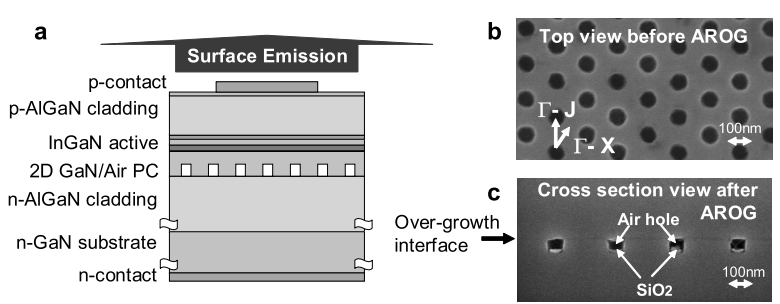

d
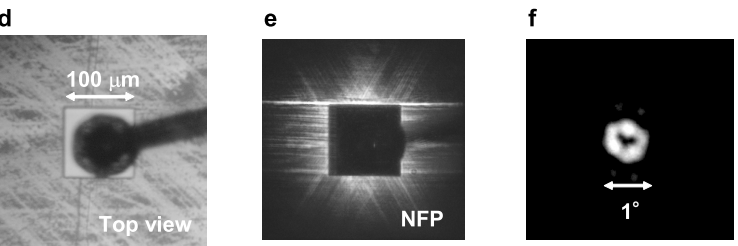

Fig. 6 (a) Schematic structure of a GaN-based photoniccrystal surface emitting laser. $^{13)}$ (b) SEM image of the triangular lattice of air holes with a period of $186 \mathrm{~nm}$, a diameter of $85 \mathrm{~nm}$, and a depth of $100 \mathrm{~nm}^{13)}$ (c) Cross-sectional SEM image of the photonic crystal, showing a well-defined GaN/air periodic structure inside the GaN epitaxial layer. ${ }^{13)}$ (d) Top view of the fabricated device with a square-shape electrode. (e) Near field pattern (NFP) and (f) beam pattern of the GaN-based photonic-crystal surface emitting laser above threshold. 
は異なり, より対称性の高い三角格子構造を用いてい る.フォトニック結晶は, 一辺 $300 \mu \mathrm{m}$ の正方形状領域 に作製した。 Fig. 6 (c)に, AROG成長後のフォトニック 結晶の断面の電子顕微鏡像を示す。空気孔上部に, $\mathrm{GaN}$ 層が綺麗に形成され，非常に良好な状態でフォトニック 結晶が形成されている様子が分かる。

こうして作製したデバイスの表面の様子を, Fig. 6 (d)に示す. 中心に一辺100 $\mu \mathrm{m}$ の正方形状の電極が形成 されており，ここから電流を注入する，室温でパルス電

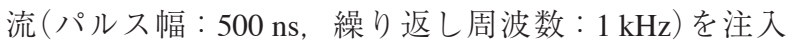
したところ、レーザー発振に成功した。Fig. 6 (e)に， 発振後の近視野像を示す。電極を中心に発振領域が等方 的に拡がっており, 2次元的に大面積で発振している様 子が分かる. Fig. 6 (f)に, 対応するビームパターンを示 す。大面積かつコヒーレントに発振していることを反映 して, 出射されたビームの広がり角は 1 程度と小さく, 中心強度の小さなドーナッツ状のパターンとなってい る.このビームの偏光は, 前節までに説明した方位偏光 および径偏光とも異なっており, 各点では直線偏光であ るが，ドーナッツの周回方向に見ていくと一周でその方 向が2回転するという特徵を有している。これは, 結晶 構造を正方格子から三角格子とすることで，新たな偏光 状態のドーナッツ状ビームが得られることを示してい る. 今後, 正方格子構造から形成される径偏光ビームと 青紫色という短波長の利点と併せることで，極限的に小 さな集光点の形成も期待される.

\section{6. まとめ}

フォトニック結晶面発光レーザーの動作原理, 結晶構 造とビームパターン, 興味深い応用および青紫色領域で の発振について解説した。垂直共振器面発光レーザー (VCSEL) とは異なり, フォトニック結晶を光共振器と する本レーザーは, 大面積での単一モード発振が可能で あり, 結晶面に垂直方向に出射されるレーザービームの 広がり角は 1 程度と非常に狭い. さらに, 結晶の空気孔 形状および結晶周期の位相ずれを制御することにより, ドーナッツ状や単峰のビームをはじめ, 多様な形状の レーザービームを実現することが可能となる，特にドー ナッツ状ビームは, 応用上重要な性質を有しており, 材 質によらない微粒子の捕捉が可能な光ピンセットの実現 や光学システムの高分解能化, 高密度化を可能にするも のと期待される。ささらに近年, 青紫色領域での発振も実 現され，短波長レーザーとしての応用も期待される。上
記の特長あるビームパターンを，半導体レーザー単体で 形成できるフォトニック結晶面発光レーザーは，デバイ スへの組み込みも容易であると考えられ，超高密度な光 記録や高解像度な光学顕微鏡といった次世代型光学シス テムの実現へつながる大きな可能性を秘めている.

謝 辞

本稿で解説した内容は，大西大，宮井英次，國師 渡, 岡野誉之, 松原秀樹, 吉本晋, 齊藤裕久, 岳江林, 田中良典各氏との共同研究で得られた成果である。こ こに感謝する次第である。なお本研究は, 科学技術振興 機構の特別研究員制度および戦略的創造研究推進事業の 支援を得て行われたものである。

\section{参考文献}

1) M. Imada, S. Noda, A. Chutinan, T. Tokuda, M. Murata, and G. Sasaki: Appl. Phys. Lett. 75 (1999) 316.

2) M. Meier, A. Mekis, A. Dodabalapur, A. Timko, R. E. Slusher, J. D. Joannopoulos, and O. Nalamasu: Appl. Phys. Lett. 74 (1999) 7.

3) S. Noda, M. Yokoyama, M. Imada, A. Chutinan, and M. Mochizuki: Science 293 (2001) 1123.

4) M. Imada, A. Chutinan, S. Noda, and M. Mochizuki: Phys. Rev. B 65 (2002) 195306.

5) E. Yablonovitch: Phys. Rev. Lett. 58 (1987) 2059.

6) E. Miyai, K. Sakai, T. Okano, W. Kunishi, D. Ohnishi, and S. Noda: Nature 441 (2006) 946.

7) D. Ohnishi, T. Okano, M. Imada, and S. Noda: Opt. Express 12 (2004) 1562.

8) M. Yokoyama and S. Noda: Opt. Express 13 (2005) 2869.

9) K. Sakai, E. Miyai, T. Sakaguchi, D. Ohnishi, T. Okano, and S. Noda: IEEE J. Sel. Areas Commun. 23 (2005) 1335.

10) K. Sakai, E. Miyai, and S. Noda: Appl. Phys. Lett. 89 (2006) 021101.

11) W. Kunishi, D. Ohnishi, E. Miyai, K. Sakai, and S. Noda: Technical Digest of Conf. on Lasers and Electro-Optics. Long Beach, May, 2006, CMKK1.

12) T. Sakaguchi, W. Kunishi, S. Arimura, K. Nagase, E. Miyai, D. Ohnishi, K. Sakai, and S. Noda: Technical Digest of Conf. on Lasers and Electro-Optics. Baltimore, May, 2009, CTuH1.

13) M. Kim, C. S. Kim, W. W. Bewley, J. R. Lindle, C. L. Canedy, I. Vurgaftman, and J. R. Meyer: Appl. Phys. Lett. 88 (2006) 191105.

14) H. Matsubara, S. Yoshimoto, H. Saito, Y. Jianglin, Y. Tanaka, and S. Noda: Science 319 (2008) 445.

15) K. Kitamura, K. Sakai, Y. Kurosaka, E. Miyai, W. Kunishi, D. Ohnishi, and S. Noda: Technical Digest of Conf. on Lasers and Electro-Optics. Baltimore, May, 2009, CTuH3.

16) K. Sakai and S. Noda: Electron. Lett. 43 (2007) 107.

17) S. Quabis, R. Dorn, M. Eberler, O. Glöckl, and G. Leuchs: Opt. Commun. 179 (2000) 1

18) A. Ashkin, J. M. Dziedzic, J. E. Bjorkholm, and S. Chu: Opt. lett. 11 (1986) 288.

19) D. Grier: Nature 424 (2003) 810.
フォトニック結晶 (photonic crystals)

屈折率の異なる材料が周期的に並んだ構造体. 固体結 晶中での電子に対するバンド構造と同様に, 光子に対す るバンド構造が形成される。バンドギャップと呼ばれる 特定の周波数帯では光の存在が禁止され, 構造中での発 光が抑制される。この中に，意図的な欠陥を導入するこ
とで, 特定周波数での発光の増強が可能となる。また, バンド端と呼ばれる点においては, 光の群速度が零とな り定在波が形成される。この定在波を利用し，2次元大 面積でコヒーレントな発振を実現するのが, フォトニッ ク結晶面発光レーザーである. 